\title{
PRELIMINARY TRIALS FOR CONTROL OF CHICKEN SALMONELLOSIS USING LYOPHILIZED IMMUNIZED EGG YOLK WITH EMPHASIIISON
}

ROFAIIL, S. K., GERMINE S. SAAD and S. B. EL-GALLAD

Veterinary Serum and Vaccine Research Institute , ARC, Dokki Giza

(Manuscript received 24 June 2014)

\begin{abstract}
$\mathrm{T}$ his study has been designed to prepare the lyophilized immunized egg yolk using different stabilizers as skimmed milk, sucrose lacto albumin and sucrose peptone. These preparations were tested in chicken against Salmonellosis. Chicken that received immunized egg yolk and experimentally infected with Salmonella typhimurium showed survival rate of $(90 \%)$ compared with the group that taken nonimmunized egg yolk (20\%). No difference in the immunogenic power of using different stabilizers with these batches. The immunogenic power of these preparations when stored at $-20^{\circ} \mathrm{C}$,

$4{ }^{\circ} \mathrm{C}$ and at room temperature for 3,6 and 9 months after injection to mice revealed that these preparations were potent when stored at $-20^{\circ} \mathrm{C}$, then at $4^{\circ} \mathrm{C}$. So lyophilized immunized egg yolks effective in protecting chicken against Salmonellosis.
\end{abstract}

\section{INTRODUCTION}

Chicken Salmonellosis is an acute highly fatal disease. The disease is enzootic and responsible for great economic losses to poultry industry where the immune deficiency status play an important role in the progress of the bacteria (Quinn et. al., 2002 and Pietro and Duncan, 2006.

Treatment of chicken Salmonellosis is often ineffective due to the presence of antibiotic drug resistant strain of Salmonella and failure to identify the drug suspcetability pattern of involved strain. Many other drugs and chemicals that can enhance various aspects of the immune response, had been tested to increase the rate of immune response against such infection (Rofaiil, 2007 and Rofaiil et. al., 2011) .

Reently great attention has been directed to the use of natural theraputic agents against many infection of which yolk of vaccinated chicken have been used for prophylaxis and treatment, as used for control of chicken Salmonellosis (Rofaiil and Saad 2013) . Little effort have been Made to investigate the role Of egg yolk in the control Salmonellosis. So this study aimed to prepare a lyophilized immunized egg yolk using different stabilizers, and to test the efficacy of these preparations when stored at different temperatures for some months in chicken and mice . 


\section{MATERIALS AND METHODS}

\section{Experimental Hens}

A total number of 20 laying hens of about 5 Months old were used for egg yolk production and another 60 chicken, of 2 weeks old age used for experimental designs.

\section{Experimental Mice}

Two hundred and fourty healthy mice each of $25 \mathrm{gm}$ were kept in isolated cages under strict Hygenic condition during the experiment.

\section{Vaccine}

Imported inactivated bivalent vaccine of Salmonella typimurium and Salmonella enteritidis were used in vaccination of chicken.

\section{Salmonella typhimurium isolate}

Local isolate of Salmonella typhimurium was used and identified by gram staining, colonial morphology biochemical and serological reactions. This strain was used for challenge test in chicken and mice as described by Forbes et al., (1998). Vaccination of hens :

Hens were divided into 2 groups (10 each), the first group was vaccinated by inactivated bivalent vaccine of salmonella with $1 \mathrm{ml}$ I/M weekly for 3 weeks as described by Ikemori et al. (1997), the other group was kept as negative control.

\section{Egg Yolk samples :}

Egg Yolk were collected weekly from non vaccinated group and 2 weeks after last vaccination of chicken for two months. It was collected in clean dry scrow capped bottles and preserved frozen till used.

\section{Stabilizers :}

The following stabilizers were used :

1- Skimmed milk : It was produced by Sketon company, Iierk, Ireland (Wyeth SMA) it was used at dilution (10\%) in distilled water and sterilized by autoclaving then added to the immunized egg yolk and non-immunized as $1: 1$ ratio.

2- Sucrose lactoalbumin : It was prepared according to Stanly and Walter(1999) then added to the immunized egg yolk and non immunized as $1: 1$ ratio.

3- Sucrose peptone : It was prepared according to Stanely and Walter(1999) by mixing $0.5 \%$ sucrose and $1 \%$ peptone then added to the immunized egg yolk and non immunized as $1: 1$ ratio..

\section{Lyophilization of immunized egg yolk yolk :}

The egg yolk fluid was mixed with different stabilizers and they were lyophilized by freeze drying method similetenuously in accord ance with Angus et al. (1977). 


\section{Experimental designs :}

Table (1) illustrate the experimental design

Table 1. experimental design for chicken :

\begin{tabular}{|c|c|c|c|c|}
\hline Group & No. & Administred preparation & Route & Challenge \\
\hline 1 & 10 & $\begin{array}{l}\text { Lyophilized immunized egg } \\
\text { yolk with skimmed milk }\end{array}$ & \multirow{7}{*}{ 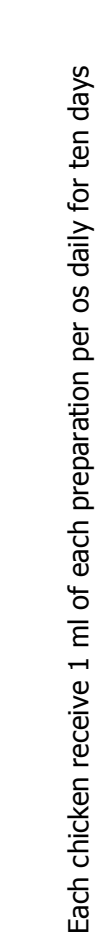 } & \multirow{7}{*}{$\begin{array}{l}\text { Each chicken in each } \\
\text { group received } 1 \mathrm{ml} \text { I/P of } \\
\text { twenty four hours broth } \\
\text { culture of salmonella } \\
\text { typhimurium containing } \\
1.5 \times 10^{8} \mathrm{CFU} / \mathrm{ml} \text { such } \\
\text { chicken observed after } \\
\text { experimental infection and } \\
\text { mortalities were recorded, } \\
\text { smears from internal } \\
\text { organs of freshly dead } \\
\text { chicken were subjected to } \\
\text { bacteriological } \\
\text { examination for } \\
\text { reisolation of the } \\
\text { organism according to } \\
\text { Forbes et al (1998) }\end{array}$} \\
\hline 2 & 10 & $\begin{array}{l}\text { Lyophilized immunized egg } \\
\text { yolk with sucrose lactoalbumin }\end{array}$ & & \\
\hline 3 & 10 & $\begin{array}{l}\text { Lyophilized immunized egg } \\
\text { yolk with sucrose peptone }\end{array}$ & & \\
\hline \multirow{3}{*}{$\begin{array}{l}4 \\
a \\
b\end{array}$} & 10 & $\begin{array}{l}\text { Lyophilized nonimmunized } \\
\text { egg yolk with skimmed milk }\end{array}$ & & \\
\hline & 10 & $\begin{array}{l}\text { Lyophilized nonimmunized } \\
\text { egg yolk with sucrose } \\
\text { lactoalbumin }\end{array}$ & & \\
\hline & 10 & $\begin{array}{l}\text { Lyophilized nonimmunized } \\
\text { egg yolk with sucrose peptone }\end{array}$ & & \\
\hline & & & & \\
\hline
\end{tabular}

\section{Keeping quality of lyophylized immunized egg yolk :}

Lyophilized immunized egg yolk with sucrose lactoalbumin for example was exposed to different temperature $\left(-20^{\circ} \mathrm{C}, 4^{\circ} \mathrm{C}\right.$ and room temperature) and stored for period of 3,6,9 months. Table (2) Illustrate the experimental design for keeping quality in mice. 
Table 2. Experimental design in mice :

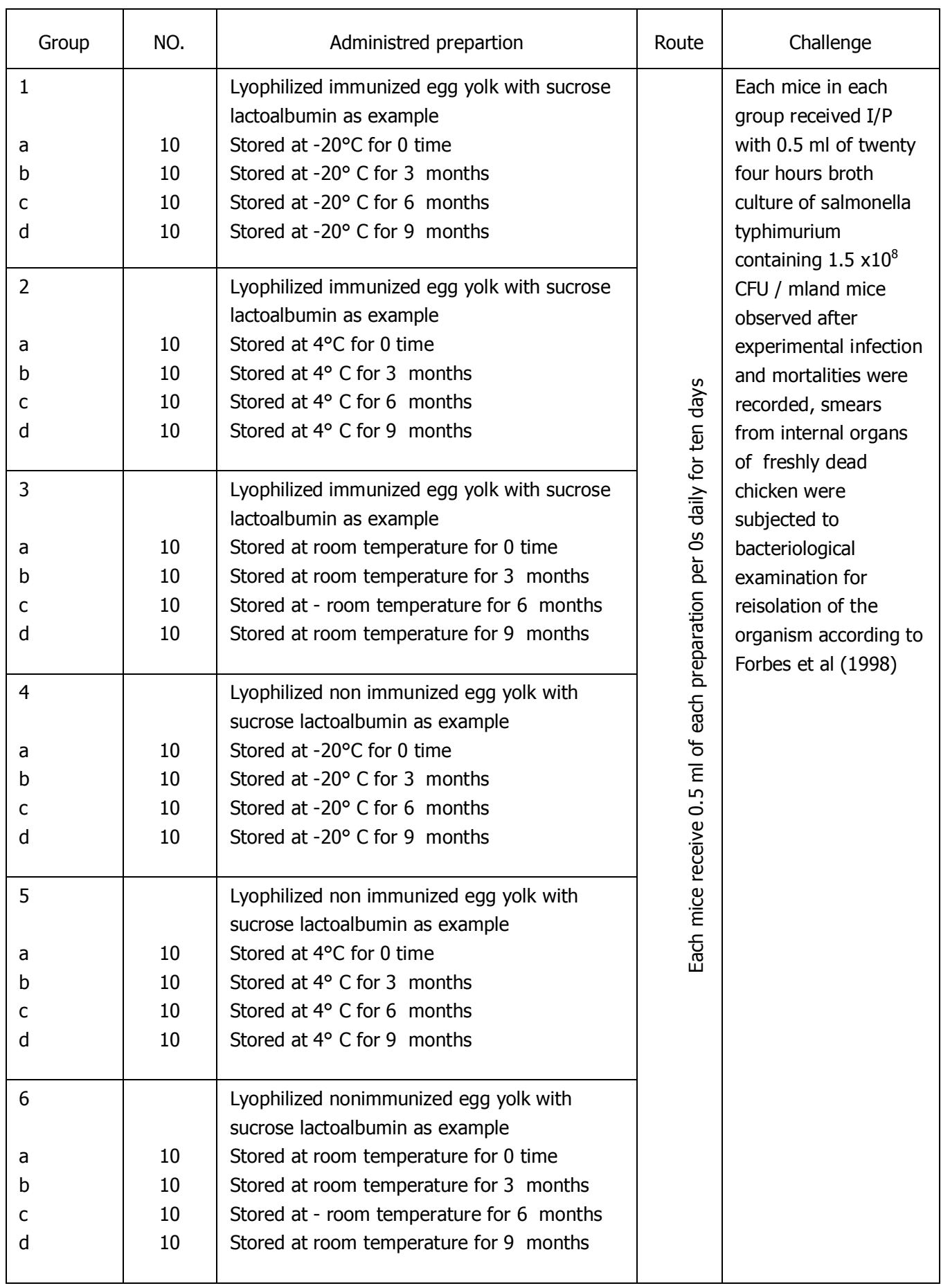

\section{RESULTS AND DISCUSSION}

This work has been designed to determine the protective potentiality of the prepared lyophilized immunized egg yolk against chicken salmonellosis using different stabilizers (skimmed milk, sucrose lactoalbumin and sucrose peptone) and to assess their keeping quality at different temperatures $\left(-20^{\circ} \mathrm{C}, 4^{\circ} \mathrm{C}\right.$ and room temperature), 
for 3,6 and 9 Months. Data presented in table (3) showed that chicken received lyophilized immunized egg yolk (with different stabilizers) resist infection with Salmonella typhimurium with survival rate reached $90 \%$ compared with $20 \%$ of the nonimmunized group. There was no difference in the immunogenic power between different stabilizers used, the antimicrobial immune response produced by treated chicken with lyophilized immunized egg yolk was similar to those obtained by Kuroski et al.(1993) who found that egg yolk immunoglobulin protect mice against experimental infection by Rota virus. Also Hiraga et al. (1990) reported that egg yolk derived from immunized hen was vintually a significant efficient source of antibodies and can prevent Rota virus infection. Egg yolk antibodies resulted from vaccination of laying hens are thought to provide a suitable source of immunity to chicken against experimental infection by Salmonella typhimurium Rofaiil and Germine saad (2013) proved that oral administration of the egg yolk to Mice could by an important tool of treatment against Salmonellosis in mice.

The strong effectivness of egg yolk antibodies to infectious pathogens also reported by (Yokoyama etal, 1992 ) who added that addition of egg yolk to the taad formula or even its application as a separate theraputic agent is helptup for Neonatal piglets.

Reisolation of bacteria from treated groups revealed absence of Salmonella typhimurium in internal organs, blood samples and even no shedding in the feaces. Meanwhile, the group received non immunized egg yolk as well as the control groups Salmonella typhimurium was detected clearly in internal organs, blood samples and shedding of the organism in the feaces was also recotded. These findings were similar to those described by (Rofaiil and Germine saad 2013).

The considerable variations affecting the immunized egg yolk potency occur during lyophilization process depends on the effect of cooling rate, residual water content, storage temperature, length of storage and thawing rate before lyophilization and the containg additive such as stabilizers include that protein or other organic compounds that may extended the shelf life or enhan el the period of the immunized egg yolk (Stanely and Walter 1999). Results of studying the effect of different temperature (-20 $\circ \mathrm{C}, 40 \mathrm{C}$ and at room temperature) on immunogenic power of lyophilized immunized egg yolk that determined in laboratory mice and challenged with Salmonella typhirium as shown in table (4) It was found that preparations kept at $-20^{\circ} \mathrm{C}$ for 3 months were the best and recorded higher immunogenic power percent $(90 \%)$. These finding are parallel to the (Nisar 1988) who found that the freezing temperature is the best for vaccine and the room temperature tail to keep the vaccine potent, also these results were almost like to those recorded by (Tina et. al., 2000), 
who recommended the storage of egg yolk at $-20^{\circ} \mathrm{C}$ for better stability. Also (Lily et. al., 2004) cleared that the prepared attenuated Rift Valley fever vaccine was being suitable for use when stored at $-20^{\circ} \mathrm{C}$ without loss in its titre.

From the above mentioned results it could be concluded that the lyophilized immunized egg yolk was safe and immunogenic as it gave up to $90 \%$ protection against Salmonella Typhimurium infection in chicken, as well as the best preservation in freezing temperature $\left(-20{ }^{\circ} \mathrm{C}\right)$ for 3 months storage can be used safely and effectively.

Table 3. Efficiency of lyophilized immunized egg yolk in chicken experimentally infected with salmonella typhimurium.

\begin{tabular}{|c|c|c|c|c|c|c|}
\hline Group & No & Admistred preparation & $\begin{array}{l}\text { No. of the } \\
\text { dead } \\
\text { chicken } \\
\text { /total No } \\
\text { of chicken }\end{array}$ & $\begin{array}{c}\text { Mortality } \\
\text { rate }\end{array}$ & $\begin{array}{l}\text { No of survived } \\
\text { chicken/total No } \\
\text { of chicken }\end{array}$ & $\begin{array}{c}\text { Protection } \\
\%\end{array}$ \\
\hline 1 & 10 & $\begin{array}{l}\text { Lyophilized immunized } \\
\text { egg yolk with skimmed } \\
\text { milk }\end{array}$ & $1 / 10$ & $10 \%$ & $9 / 10$ & $90 \%$ \\
\hline 2 & 10 & $\begin{array}{l}\text { Lyophilized immunized } \\
\text { egg yolk with sucrose, } \\
\text { lactoalbumin }\end{array}$ & $1 / 10$ & $10 \%$ & $9 / 10$ & $90 \%$ \\
\hline 3 & 10 & $\begin{array}{l}\text { Lyophilized immunized } \\
\text { egg yolk with sucrose } \\
\text { peptone }\end{array}$ & $1 / 10$ & $10 \%$ & $9 / 10$ & $90 \%$ \\
\hline $4 a$ & 10 & $\begin{array}{l}\text { Lyophilized non- } \\
\text { immunized egg yolk } \\
\text { with skimmed milk }\end{array}$ & $8 / 10$ & $80 \%$ & $2 / 10$ & $20 \%$ \\
\hline$b$ & 10 & $\begin{array}{lr}\text { Lyophilized } & \text { non- } \\
\text { immunized egg yolk } \\
\text { with sucrose lacto } \\
\text { albumin }\end{array}$ & $8 / 10$ & $80 \%$ & $2 / 10$ & $20 \%$ \\
\hline c & 10 & $\begin{array}{l}\text { Lyophilization non- } \\
\text { immunized egg yolk } \\
\text { with sucrose peptone }\end{array}$ & $8 / 10$ & $80 \%$ & $2 / 10$ & $20 \%$ \\
\hline
\end{tabular}


Table 4 . keeping quality of lyophilized immunized egg yolk determined by mice experimentally infected with salmonella typhimurium.

\begin{tabular}{|c|c|c|c|c|c|c|}
\hline $\begin{array}{c}\text { Grou } \\
\mathrm{p}\end{array}$ & NO. & administred preparation & $\begin{array}{c}\text { No. of } \\
\text { dead } \\
\text { mice } \\
\text { /total No } \\
\text { of mice }\end{array}$ & $\begin{array}{c}\text { Mortality } \\
\text { rate }\end{array}$ & $\begin{array}{c}\text { No of } \\
\text { survived } \\
\text { mice } \\
\text { /total no } \\
\text { of mice } \\
\end{array}$ & $\begin{array}{c}\text { Protectio } \\
\text { n } \\
\%\end{array}$ \\
\hline $\begin{array}{l}1 \\
\text { a } \\
b \\
c \\
\text { d }\end{array}$ & $\begin{array}{l}10 \\
10 \\
10 \\
10\end{array}$ & $\begin{array}{l}\text { Lyophilized immunized egg yolk with } \\
\text { sucrose lactoalbumin as example } \\
\text { Stored at }-20^{\circ} \mathrm{C} \text { for } 0 \text { time } \\
\text { Stored at }-20^{\circ} \mathrm{C} \text { for } 3 \text { months } \\
\text { Stored at }-20^{\circ} \mathrm{C} \text { for } 6 \text { months } \\
\text { Stored at }-20^{\circ} \mathrm{C} \text { for } 9 \text { months }\end{array}$ & $\begin{array}{l}1 / 10 \\
1 / 10 \\
3 / 10 \\
4 / 10\end{array}$ & $\begin{array}{l}10 \% \\
10 \% \\
30 \% \\
40 \%\end{array}$ & $\begin{array}{l}9 / 10 \\
9 / 10 \\
7 / 10 \\
6 / 10\end{array}$ & $\begin{array}{l}90 \% \\
90 \% \\
70 \% \\
60 \%\end{array}$ \\
\hline $\begin{array}{l}2 \\
a \\
b \\
c \\
d\end{array}$ & $\begin{array}{l}10 \\
10 \\
10 \\
10\end{array}$ & $\begin{array}{l}\text { Lyophilized immunized egg yolk with } \\
\text { sucrose lactoalbumin as example } \\
\text { Stored at } 4^{\circ} \mathrm{C} \text { for } 0 \text { time } \\
\text { Stored at } 4^{\circ} \mathrm{C} \text { for } 3 \text { months } \\
\text { Stored at } 4^{\circ} \mathrm{C} \text { for } 6 \text { months } \\
\text { Stored at } 4^{\circ} \mathrm{C} \text { for } 9 \text { months }\end{array}$ & $\begin{array}{l}3 / 10 \\
3 / 10 \\
4 / 10 \\
4 / 10\end{array}$ & $\begin{array}{l}30 \% \\
30 \% \\
40 \% \\
40 \%\end{array}$ & $\begin{array}{l}7 / 10 \\
7 / 10 \\
6 / 10 \\
6 / 10\end{array}$ & $\begin{array}{l}70 \% \\
70 \% \\
60 \% \\
60 \%\end{array}$ \\
\hline $\begin{array}{l}3 \\
\text { a } \\
b \\
c \\
d\end{array}$ & $\begin{array}{l}10 \\
10 \\
10 \\
10\end{array}$ & $\begin{array}{l}\text { Lyophilized immunized egg yolk with } \\
\text { sucrose lactoalbumin as example } \\
\text { Stored at room temperature for } 0 \text { time } \\
\text { Stored at room temperature for } 3 \text { months } \\
\text { Stored at - room temperature for } 6 \text { months } \\
\text { Stored at room temperature for } 9 \text { months }\end{array}$ & $\begin{array}{l}4 / 10 \\
4 / 10 \\
5 / 10 \\
5 / 10\end{array}$ & $\begin{array}{l}40 \% \\
40 \% \\
50 \% \\
50 \%\end{array}$ & $\begin{array}{l}6 / 10 \\
6 / 10 \\
5 / 10 \\
5 / 10\end{array}$ & $\begin{array}{l}60 \% \\
60 \% \\
50 \% \\
50 \%\end{array}$ \\
\hline $\begin{array}{l}4 \\
\text { a } \\
b \\
\text { c } \\
\text { d }\end{array}$ & $\begin{array}{l}10 \\
10 \\
10 \\
10\end{array}$ & $\begin{array}{l}\text { Lyophilized non immunized egg yolk with } \\
\text { sucrose lactoalbumin as example } \\
\text { Stored at }-20^{\circ} \mathrm{C} \text { for } 0 \text { time } \\
\text { Stored at }-20^{\circ} \mathrm{C} \text { for } 3 \text { months } \\
\text { Stored at }-20^{\circ} \mathrm{C} \text { for } 6 \text { months } \\
\text { Stored at }-20^{\circ} \mathrm{C} \text { for } 9 \text { months }\end{array}$ & $\begin{array}{l}8 / 10 \\
8 / 10 \\
9 / 10 \\
9 / 10\end{array}$ & $\begin{array}{l}80 \% \\
80 \% \\
90 \% \\
90 \%\end{array}$ & $\begin{array}{l}2 / 10 \\
2 / 10 \\
1 / 10 \\
1 / 10\end{array}$ & $\begin{array}{l}20 \% \\
20 \% \\
10 \% \\
10 \%\end{array}$ \\
\hline $\begin{array}{l}a \\
b \\
c \\
d\end{array}$ & $\begin{array}{l}10 \\
10 \\
10 \\
10\end{array}$ & $\begin{array}{l}\text { Lyophilized non immunized egg yolk with } \\
\text { sucrose lactoalbumin as example } \\
\text { Stored at } 4^{\circ} \mathrm{C} \text { for } 0 \text { time } \\
\text { Stored at } 4^{\circ} \mathrm{C} \text { for } 3 \text { months } \\
\text { Stored at } 4^{\circ} \mathrm{C} \text { for } 6 \text { months } \\
\text { Stored at } 4^{\circ} \mathrm{C} \text { for } 9 \text { months }\end{array}$ & $\begin{array}{l}8 / 10 \\
8 / 10 \\
9 / 10 \\
9 / 10\end{array}$ & $\begin{array}{l}80 \% \\
80 \% \\
90 \% \\
90 \%\end{array}$ & $\begin{array}{l}2 / 10 \\
2 / 10 \\
1 / 10 \\
1 / 10\end{array}$ & $\begin{array}{l}20 \% \\
20 \% \\
10 \% \\
10 \%\end{array}$ \\
\hline $\begin{array}{l}a \\
b \\
c \\
d\end{array}$ & $\begin{array}{l}10 \\
10 \\
10 \\
10\end{array}$ & $\begin{array}{l}\text { Lyophilized nonimmunized egg yolk with } \\
\text { sucrose lactoalbumin as example } \\
\text { Stored at room temperature for } 0 \text { time } \\
\text { Stored at room temperature for } 3 \text { months } \\
\text { Stored at - room temperature for } 6 \text { months } \\
\text { Stored at room temperature for } 9 \text { months }\end{array}$ & $\begin{array}{l}8 / 10 \\
8 / 10 \\
9 / 10 \\
9 / 10\end{array}$ & $\begin{array}{l}80 \% \\
80 \% \\
90 \% \\
90 \%\end{array}$ & $\begin{array}{l}2 / 10 \\
2 / 10 \\
1 / 10 \\
1 / 10\end{array}$ & $\begin{array}{l}20 \% \\
20 \% \\
10 \% \\
10 \%\end{array}$ \\
\hline
\end{tabular}




\section{ACKNOWLEDGMENT}

The authors would give thanks to prof. Dr. Roukaya Mohamed Osman for her scientific advice and guidance to accomplish this work.

\section{REFERENCES}

1. Angus, R.D. lowe, E.L. and Pietz D.E. 1977 . Evaluation of five media for stabilization of Brucella abortus strain 19 described by lyophilization. Dev. Bio. Stand 36 :307-312.

2. Forbes, B.A.D Sohu, F and Weiss field, K.S. 1998 . Baily and Scotts diagnostic microbiology, Moslny st. Louis.

3. Hiraga, CY, Kodama, $T$ and Chikoura, Y.T. 1990. Prevention of Human rota virus infection with chicken egg yolk immunoglobulins containing rota virus antibodies . J. Jap avoc. infect. dis. $64: 118-123$

4. Ikemori, Y.M, Ohta, M, Uneda, K, Catla, S.M., Yokoy and Kodama. Y. 1997. Passive protection of Neonatal calves against bovine corona virus induced diarrhea by administration of egg yolk or colostrum antibody powder. Vet. microbiol 58 (2-4) 105-111.

5. Kuroki, M, M, Ikemori , H., Yokoyama R.C. Pernatta F.C. and kodama, Y 1993.

Passive protection against Bovine Rota virus induced diarrhea in Murine model by specific immunoglobulin from chicken egg yolk. Vet. Microbiol, 37 (1-2): 135145.

6. Lily, S.S., Marcoss, T.N, Gihan, K.M. sly, K.A. and Ibrahim, A.M. 2004. Trials for using skimmed milk as stabilizer for attenuating Rift Valley fever virus vaccine. J. Agic. Res. 82 (4) :1905-1915.

7. Nisar, A. 1988. Post vaccination antibody profile of haemorrhagic septicemia in adult cattle. Thesis M.Sc college of Vet Science, La Hore.

8. Pietro, M and dun can, M. 2006. Salmonella infectious, clinical immunological and molecular aspects. 1st., Ed. Cambridge University press.

9. Quinn P.J. , Markery, B.K. caste, M.E., Donnelly. W.J. and leased f.c. 2002. Veterinary microbiology and microbial disease. 1st published black well, science, LTD UK.

10. Rofaiil, S.k. 2007. Studies on some additives for reducing some enteric bacteria infection in swiss Mice. J. Egypt Vet. Med. assoc. 67 (1) : 233-239. 
11. Rofaiil, S.K. and Germine, S. Saad. 2013. Effectiveness of protective potentials of chicken egg yolk in controlling Salmonellosis using laboratory Mice as a model. J. Agric. Res. 91 (1) : 323 -334.

12. Rofaiil, S.K., Rogaa, A.S, ola A, E and mahmoud, m.H. 2011. Studies on some medicinal plant extract as immune stimulant in rats experimentally infected with Salmonella typhimurium J. agric. Res. 89 (1) : 336-343.

13. Stanely , A.P and Walter A.O. 1999. Vaccines, overview of vaccine manufacturing and quality assurance, 40-46 chapter 4. 3rd ed. philadelphia, London, toronto, Tokyo.

14. Tina, D. J, Adel, K, A and Ofarrelly, C. 2000. Comparative analysis of methods of purification of egg yolk immunoglobulin. Food Agric. immunol. 12 : 77-85.

15. Yokoyama, HRC., perolt, R, Diaz, S, Sorda, Yikenor. 1992. Panine protective effect of chicken egg yolk immunoglulinic eschericha coli infection in Neonatal piglets. infect. immun. 60(3) : 998-1007. 


\section{محاو لات مبائية للسيطرة علي سالمونيلا الاجاج باستخدام}

صفار البيض المناعي المجفد و دراسة كفاعته

\section{صفوت كمال روفائيل جرمين صبحي سعد ،

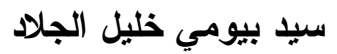

$$
\text { معهد بحوث الأمصال و اللقاحات البيطرية- مركز البحوث الزراعية - الدقي - الجيزة }
$$

أجريت هذه الدر اسة لتحضير صفار البيض المناعي المجفد و ذلك باستخدام عدة مواد مثبتة

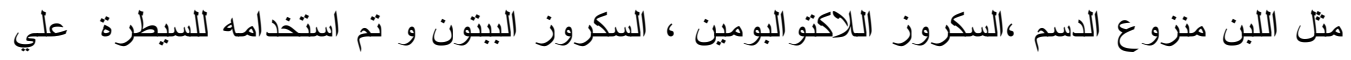

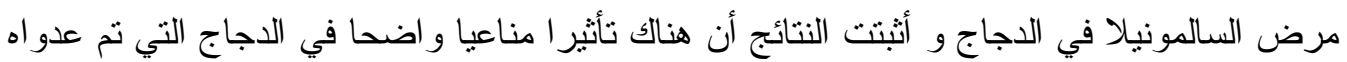
بالسالمونيلا تيفيميوريم و سبق معالجته بالمنتج المحضر حيث كانت نسبة الدجاج الذي لم ينفق و لم

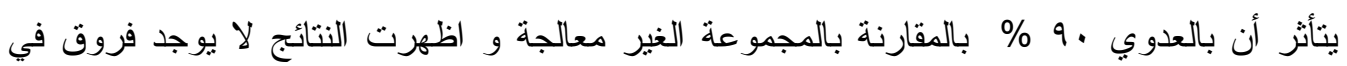

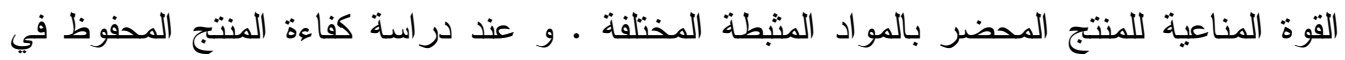

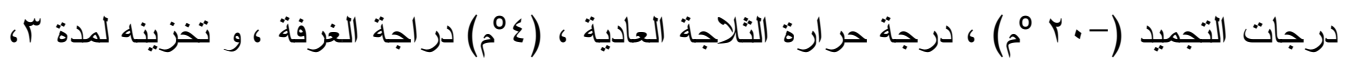
7 ، 9 شهور تم قياس القوة المناعية لكل هذه العو امل علي حدة في الفئران المعملية بعد عدواها

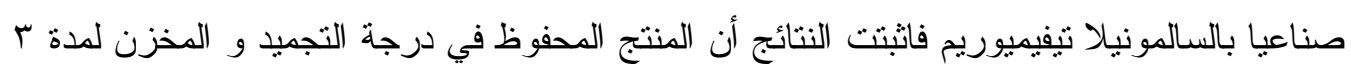
شهور أحتفظ بقوته المناعية. من خلال تلك الدراسة يمكن أن يوصي بإمكانية استخدام صفار البيض المناعي المجفد و

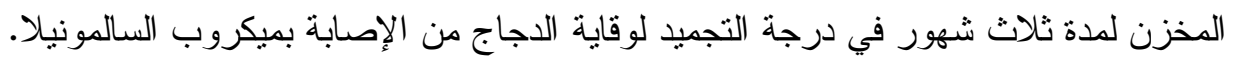

